UDC 343.9(5):341.362.1

DOI: https://doi.org/10.32631/pb.2019.4.10

MOHAMMAD ALI ZOHOURIAN

Ph.D. Candidate, South China Sea Institute, Xiamen University,

Xiamen, 361005, mazohourian@gmail.com

\title{
STATISTICAL COMPARISON OF PIRACY AND ARMED ROBBERY WITH EMPHASIS ON THE SOUTH CHINA SEA - MALACCA STRAIT AND THE PERSIAN GULF - STRAIT OF HORMUZ
}

\begin{abstract}
International trading flows have always been the subject of geopolitical risks and conflicts. Different stages of the supply chain, trade always face inherent challenges caused by geopolitical realities along given routes. In this study, the data concerning piracy and armed robberies of ships reported to the Global Integrated Shipping Information System were considered. The statistics include the information on the incidents during the period between 1998 and 2018 on different types of ships, in two most strategic areas, namely the South China Sea (SCS) and the Strait of Malacca (area 1) and the Strait of Hormuz and the Persian Gulf (area 2). According to the GISIS reports, most of the incidents occurred in the South China Sea and the Strait of Malacca are respectively 1684 and 610. Because of the importance of both the Strait of Hormuz and the Malacca Strait as the most vital waterway in the world, it is necessary to have a clear picture of the security situation in the two aforementioned Straits. This research allowed us: 1) to make a distinction between the security in two aforementioned areas; 2) to represent the source of the information for researchers.
\end{abstract}

Keywords: The Persian Gulf, The Strait of Hormuz, The Malacca Strait, The South China Sea, Piracy and Armed Robbery

Original article

\section{Introduction}

The piracy acts date back to the second millennium in the Minoan Mycenaean world. (Caskey 1969) Maritime safety of many countries is at risk because of piracy and armed robbery issues.(Barrios 2005) Nowadays, one of the main threats facing the international shipping community in the Gulf of Guinea, the South China Sea, the Western Indian Ocean, and the Strait of Malacca, in the territorial waters off Somalia, is armed robbery and piracy. Although the statistics from various reporting centers differ, the fact is that the Far East, including the Malacca Strait, Indonesia and the South China Sea, is the territory where most of the reported incidents took place in 2015. Incidents varied from theft and robbery in port to hijacking of vessels. It should be noted, in this study armed robbery against ships (in territorial and internal waters) and any attempted acts or reported acts of piracy (in international waters) are considered as reported incidents. The Straits of Hormuz and Malacca are considered as the most strategic territories. A large volume of oil is exported to Asia or other areas through the Strait of Hormuz, the geopolitical strait connecting the Persian Gulf to the Indian Ocean ${ }^{1}$. This

${ }^{1}$ Read Strait of Hormuz is chokepoint for 20\% of world's oil, U.S. ENERGY INFO. ADMIN. (Sept. 5, 2012),
Strait is one of the most important oil transit routes. According to the U.S. Energy Information Administration, total flows through the Strait of Hormuz had been 18.5 and the Malacca Strait 16 million barrel per day until 2016.(EIA 2017a) The depth and width of the Malacca Strait allow the passing of the biggest oil tankers, which provide over $65 \%$ of total oil shipments delivered by tankers with the bearing capacity of 150,000 tons.(EIA 2012a) Problems or breaks concerning oil export through the Strait of Hormuz can influence world oil cost extremely. Despite the fact that destination of most flows through the Hormuz Strait is Asia, the world cost of oil depends on any disruption there.(Katzman et al. 2012) Two important issues concerning the Strait of Hormuz relevant to Iran should be mentioned as it is one of the most critical transit chokepoint. The first derives from the geographical position of the Strait of Hormuz. Iranian role in comanaging the Hormuz Strait according to international laws and protecting own state interests and rights is the second issue(Nazemroaya 2012). The Iranian Regular Force Navy and the Iranian Revolutionary Guard Navy compose Iranian naval forces and have the important role for successful maritime traffic through Hormuz. The Strait of

http://www.eia.gov/todayinenergy/detail.cfm?id=7830 [http://perma.cc/RN3J-DSJV] (archived Feb. 16, 2014). 
Hormuz is controlled and monitored by Iranian naval forces via Omani enclave of Musandam. Iranian territorial waters are sailed through by world maritime traffic as well as the U.S. Navy. Entrancing into the Persian Gulf is possible through Iranian waters and exits are through waters of Oman (Nazemroaya 2012).

There is another famous strait in the world namely the Malacca Strait. About $50 \%$ of the world's crude oil(Kevin X. Li; Jin Cheng 2006)and A third of the world's trade is passed through the aforementioned Strait.(Huang 2008) Yun Yun Teo claims in his report Target Malacca Strait that in the cases of terroristic attacks Singapore is at the highest risk because of its important geographical location and its port's depth, also as it is a local oilrefining hub and the busiest container port in located there.(Teo 2007) Investigating piracy issue in the different areas such as the South China Sea and the Malacca Strait is a continuing concern within international researches Also different aspects of piracy and armed robberies have been explored by many scholars, for example, J.N Mak has discussed regionalism and unilateralism in the Malacca Strait,(J.N. Mak 2006) Ian Storey explored effective measures on improvement of maritime security in the Southeast.(Storey 2008) Max Mejia described piracy and another crimes at sea from perspective of IMO instruments.(Mejia 2003) Also Yun Yun Teo discussed maritime terrorism in Southeast Asia.(Teo 2007) Some scholars paid attention to the history of piracy in Late Roman and Viking Ages.(Jones 1926; Pearson 2006) In addition, a group of scholars or lawyers has examined the other subjects relating to piracy, such as, sovereign right,(Woolley 2010) combating,(Bornick 2005; J. Ho 2009; MO 2002) transport,(Vespe, Greidanus, and Alvarez 2015) protection of foreign ship)Jesus 2003)etc. The role of the Strait of Hormuz and the Malacca Strait is extremely important, that is why it is necessary to have complete understanding of the situation of security in this territory. Although, statistical data vary in international reports, we can see obvious consensus among scholars on serious threats and risks of piracy and armed robbery in the Malacca Strait and the South China Sea, However, there is no study regarding statistical comparison between two important areas, including the Persian Gulf and the South China Sea, the Strait of Hormuz and the Malacca Strait.

The research is focused on the comparison of piracy and armed robberies during two decades (1998-2018). This analysis is based on the data received from Global Integrated Shipping Information System (GISIS), recorded by International Maritime Organization (IMO) Member States from January, 1998 until December, 2018. This comparison is carried out in the two areas. The first area is the South China Sea, and the Malacca Strait and the second area is the Strait of Hormuz and the Persian Gulf. Besides, these areas have been the main and ancient route of Maritime Silk Road (MSR). There is a wide variety of researches investigating piracy and armed robberies in the important areas, such as the South China Sea and the Malacca Strait, however, a little attention has been paid to the statistical comparison concerning these three areas. The issue of security in MSR has grown in importance in light of increasing number of incidents. This article assesses the security situation of the MSR from the view of the IMO statistics as no previous study has investigated this aspect. The analytical comparison could be given in such aspects: 1) point out the difference of insecurity status between the SCS and the Strait of Malacca as area 1 and the Persian Gulf and the Strait of Hormuz as area 2 , and 2) represent the source of the statistic comparison. Moreover, this study provides an opportunity to advance our knowledge about the incidents in different maritime zones. To achieve this purpose, IMO's reports have been used for the statistical comparison, though it seems not all incidents are reported by ship owners as well as some shipping companies does not allow shipmasters to report pirate attacks because of bad influence on the company's image or being detained inordinate in harbor for investigation. Nonetheless IMO's reports give us the proper picture with regard to the situation of security in these areas.

\section{Description}

There is no doubt, the most important vital lifelines of Asia and the world, strategically, economically, politically are the Straits of Hormuz and Malacca. Examining the IMO's statistic data on occurred events is the best way to analyze and compare the situation of security in these Straits. It should be noted that due to infliction of harm upon all maritime nations on the seas, piracy is treated as a universal crime by international law, and any state is potentially able to arrest and punish the perpetrators.(Barrios 2005) The waters of the South China Sea and the Malacca Strait have proved to be a dangerous area for the shipping industry because of these types of crimes. IMO as the forerunner of the international efforts has combated piracy and armed robberies. This is visible by sets of international instruments adopted by the IMO regarding this matter.(Attard 2014) In this connection, it is necessary to mention, IMO adopted the Resolution in 2009 pursuant to Resolution 
A.545 (13) ${ }^{1}$, "Governments should inform the IMO about any act of piracy or armed robbery committed against ships flying of their country". Data including location and circumstances of the incident and the action taken by the costal state should be reported to the $\mathrm{IMO}^{2}$. The States should provide reports of incidents committed against ships flying under their flag. ${ }^{3}$ These monthly reports include the details such as ${ }^{4}: 1$. Ship's name, type, IMO number; 2 . The incident's date and time; 3 . Exact location of the incident; 4. Incident details; 5 . Consequences for the crew; 6 . Actions taken by the master/crew; 7 Actions taken by Coastal State; 8 . Weapons used by attackers and other information.

The International Maritime Organization is the most important institutionalized source of maritime security law in spite of existing many others. IMO has promulgated a number of guidelines and recommendations in framework of circulars in retaliation to the prevention and suppression of piracy and armed robbery at sea.(Attard 2014) A numerous attacks during the early 1980 s prompted IMO to make decision by adoption of Resolution A.545 (13) ${ }^{5}$. This Resolution invited Governments to provide statistical analysis of all incidents which were committed against their ships flying their flag6. The Resolution calls Governments, ship owners, ship masters, ship operators, and crew to take all necessary security measures "to prevent and suppress acts of piracy and armed robbery against ships in or adjacent to their waters"7. Therefore, the government's reports assisted IMO to collect data reports. IMO has commenced to take measures through adoption of Resolution A.545 since 1980 $(13)^{8}$. Many new resolutions followed after Resolution A.545 (13), they were focused on putting efforts in the whole world to combat piracy and armed robbery at sea. In this regard, pursuant to the mentioned above Resolution, IMO also adopted two documents - Resolution A.683 (17) ${ }^{9}$ and

1 Resolution A.545 (13), "Measures to prevent acts of piracy and armed robbery against ships", adopted on 17 November, 2009.

${ }^{2}$ Id. para. 4.

3 Id., para. 4

${ }^{4}$ IMO MSC.4/Circ. 64, May 5, 2005.

5 Measures to Prevent Acts of Piracy and Armed Robbery against Ships, IMO Resolution A.545 (13) (17 November 1983).

${ }^{6}$ IMO Resolution A.545 (13), para.4.

${ }^{7}$ IMO Resolution A.545 (13), para. 2.

8 IMO Resolution A.545 (13), "Measures to Prevent Acts of Piracy and Armed Robbery against Ships," 17 November 1983.

9 "Prevention and Suppression of Acts of Piracy and Armed Robbery against", 6 November 1991.
Resolution A.738 (18) 10 in 1991 and 1993. Resolution A.683 (17) on the "Prevention and Suppression of Acts of Piracy and Armed Robbery against Ships"11 urged governments to exert all powers to reduce the number of incidents of piracy and armed robbery at sea ${ }^{12}$. Furthermore, Resolution A.738 (18) named "Measures to Prevent and Suppress Piracy and Armed Robbery against Ships"13, also called Governments inter alia to withstand attacks, and also urged them to develop and support close liaisons with neighboring countries to facilitate the apprehension and punishment of all people participating in those piratical incidents ${ }^{14}$.

IMO also has an important role to issue abundant codes, recommendation to Government, and guidelines to prevent piracy and armed robbery against vessels. Hence, IMO issued recommendations in 1993 and they were published as a Circular, then revised in 1999, 2009, and more recently in 2015. The Circular provides steps that should be taken to reduce the risk of such attacks, moreover, it emphasizes the vital need to report attacks (both successful and unsuccessful) to the appropriate authorities of the relevant coastal State ${ }^{15}$. IMO MSC.4/Circ.1334 invites Coastal States/port States to report to IMO "any act of armed robbery in their waters or acts of piracy close to their waters which have been reported to them"16. Since 2004, the IMO has decided to put transparency on its agenda through the effective use of information and communication technologies. Then, in 2005, IMO launched the Global Integrated Shipping Information System (GISIS) to permit Member States to report directly according to the international rules and access to information ${ }^{17}$. Moreover, IMO has issue incident report on piracy and armed robbery since 1982 using data submitted by Member Governments and appropriate international organizations. Since July 2002, IMO's monthly and annual reports regarding piracy and armed robbery have been classified separately, all occurred attacks or attempts of piracy in international waters and crimes in territorial waters.(IMO n.d.) Every month these reports are published and contain the details of the incidents, such as IMO number, and flag, date and time, position of the incident;

10 "Measures to Prevent and Suppress Piracy and Armed Robbery against Ships", 4 November 1993.

11 IMO Resolution A.683(17) (6 November 1991).

12 Id., para. 1.

13 IMO Resolution A.738(18) (4 November 1993).

14 Id., para.6.

15 IMO MSC.4/Circ.1334, 23 July, 2009.

16 MSC.1/Circ.1333/Rev.1, 12 June, 2015, para.18.

17 . Resolution A.1029(26), 26 November 2009. 
Ship's type, action taken by the master and the crew, consequences for the crew, ship and cargo.(Balkin 2006) The incidents of piracy and armed robbery are reported separately from acts of armed robbery happened in ports and attempted acts of armed robbery since July, 2002 according to the initiative of IMO Secretariat.(J. Ashley Roach 2011) This classified information is more detailed for analysis and data reporting purposes ${ }^{1}$. According to the information, provided by IMO report on piracy and armed robbery at sea, in March 2013 the total number of incidents was 23, and most of them happened in port areas ${ }^{2}$.

\section{Analysis}

This part of the research demonstrates the findings which emerged from the statistical analysis presented in this article. The Current data regarding incidents have been derived to provide the evidence required for this study from the Global Integrated Shipping Information System (GISIS) with a focus on the period of past 20 years, January 1, 1998 - June 31, 2018. The target areas in this study comprise different types of ships, in two most strategic areas, namely the South China Sea (SCS) and the Strait of Malacca (area 1) and the Strait of Hormuz and the Persian Gulf (area 2).

\subsection{The Malacca and Singapore Straits}

The Strait of Malacca is wide enough at it opens to the Andaman Sea.(Emran 2007) It, being sufficiently large in the north, is getting considerably narrower to the south, in particular between the Indonesian Province of Riau and the Malaysian state of Johor and between the Indonesian Riau Islands and Singapore.(Djalal 1999) The length of the Strait of Malacca is 500 miles and its width varies from 220 miles to 10 miles,(Keyuan 2000) with diverse depths from over 70 to less than 10 meters.(Koto, Rashidi, and Maimun 2013) The mainland Malay Peninsula is separated from the Indonesian island of Sumatra by the Strait of Malacca, forming a funnel shaped watercourse as it narrows to the south. The Strait of Bengkali, Strait of Rupat, and Strait of Johor are located along the Malacca Strait.(George 2008) It is in the south and finishes in the territory between Malaysia and Indonesia. The area between the island Republic of Singapore and the islands of Riau of Indonesia is joined by the Strait of Singapore.(Sivaguru 2008) The length of the Strait of Singapore is about 60 miles, its importance is

${ }^{1}$ IMO MSC.4/Circ. 196, Reports on Acts of Piracy and Armed Robbery against Ships, 29 April 2013.

2 Id., Annex 1 and 2. stemmed from being a gateway to the SCS, which is joined to the Pacific Ocean. The Strait of Singapore's narrowest width is only a little more than one kilometer(Oei 2003) and it is bordered by Singapore, Indonesia, and Malaysia.(Hazmi 2011).

\subsection{The Importance of the Malacca Strait}

During many centuries the main goods transferred by the Malacca Strait were spices, camphor and nutmegs, in the $21^{\text {st }}$ century the crude oil, petroleum products, electronic devices, vehicles are transferred by Maritime Silk Road. But it is a risky territory for international navigation due to collisions, happening in many seaports. (Zaman et al. 2015) In the other word this Straits are ancient and trading route)Rusli 2012). Local and international trade depend on the situation in international navigation waterway, that is why the role of the Malacca Strait is extremely important. )Sien 1998) (Rahman, Saharuddin, and Rasdi 2014) It is reported to Marine Department of Malaysia that the total number of vessels navigating from Western to Eastern region was 18021 units in 2000 and it was 26776 units in 2012 from Eastern to Western region.(Rahman, Saharuddin, and Rasdi 2014) According to the analysis of the Malaysian Marine Department's STRAITREP the passage amount from 71359 in 2009 rose to 82644 in 2018 by carrying various cargoes, (Marine Department Malaysia n.d.) from raw materials to produced goods, delivered to different countries, (V. L. Forbes 2004) about $80 \%$ of oil is imported to China by the Straits. The Middle East countries imported goods and products to China amounting nearly 40 billion American dollars in 2006. (Gilmartin 2008) The Dover Strait is a significant chokepoint, which joins the North Sea and the Atlantic Ocean. Due to the density of navigation, the Malacca Strait and the Strait of Singapore are almost as intense as the Dover Strait.(Graham 2006) pp. 155e160). (Rusli 2012) The Straits of Malacca and Singapore have won the reputation of the most crucial shipping world lanes and the longest international navigated straits. (J. H. Ho 2009) These Straits are the strategically important for shipping oil from the Persian Gulf to Eastern and Southeastern countries in Asia.(Sien 1998).

\subsection{The Strait of Malacca}

The figure 1 demonstrates the amount of incidents in the Malacca Strait during 1998-2018. The most crimes occurred in territorial sea (250), this number slightly declined to 226 in international waters. The lowest number of cases was in port area and amounted to 134.(GISIS 2019). 


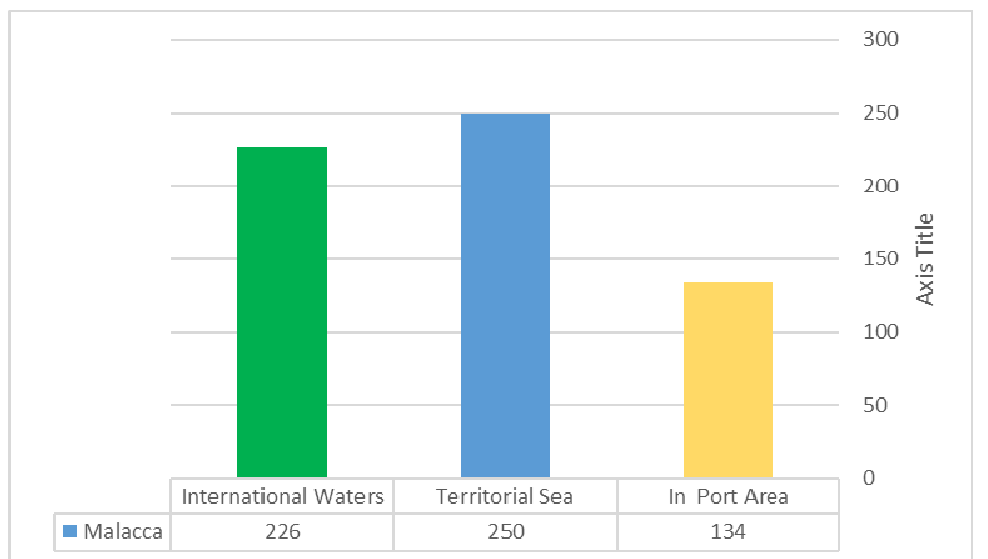

Figure 1. Total number of Incidents in the Malacca Strait(GISIS 2019)

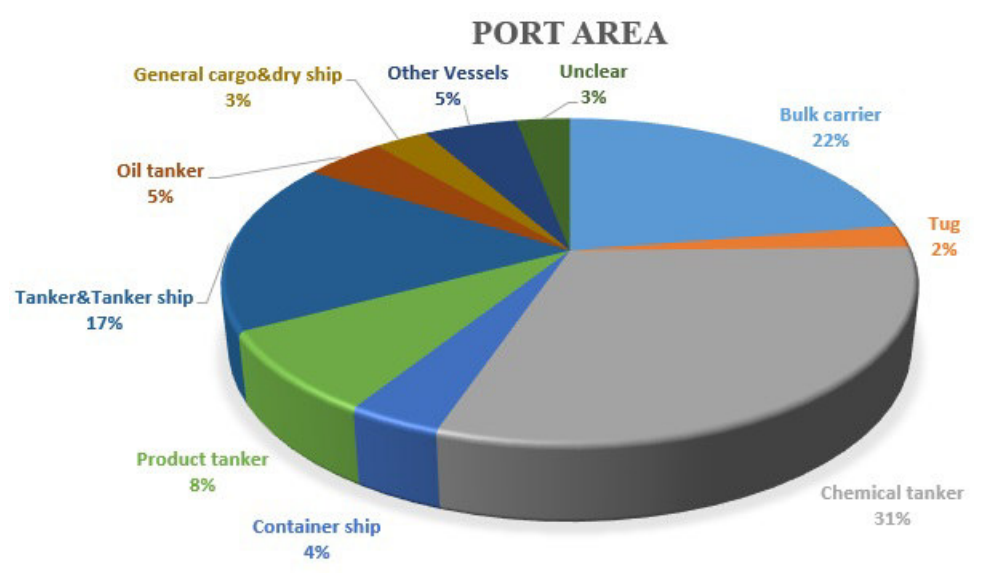

Figure 2. The Incidents in Port Area of the Malacca Strait(GISIS 2019)

The figure 2 illustrates the amount of different types of ships which were attacked by pirates or underwent the armed robbery. The biggest persantage of attacks were on chemical tankers (31\%), and bulk carriers (22\%). Tankers were chosen in $17 \%$ of all the cases. Product tankers were captured in $8 \%$ of cases, while container ships and oil tankers had $4 \%$ and $5 \%$ correspondingly. General cargo\&dry ships and tugs were attacked in $3 \%$ and $2 \%$ cases, and other vessels had 5\%.(GISIS 2019).

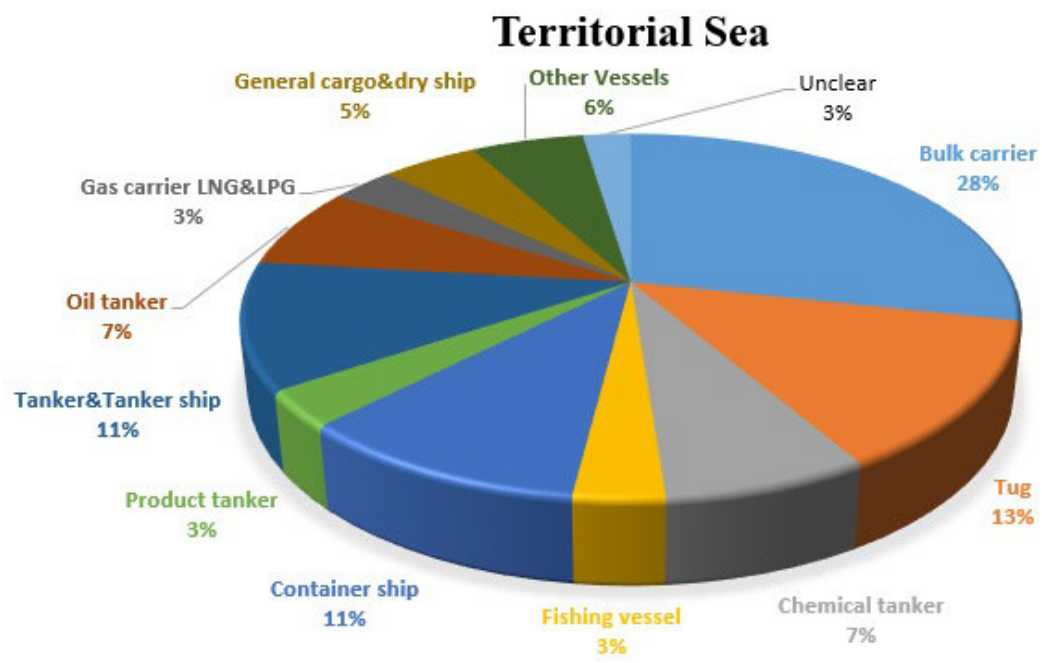

Figure 3.The Incidents in theTerritorial Sea of the Malacca Strait (GISIS 2019) 
Diagram 3 shows the types of vessels atacked in territorial sea of the Malacca Stright. The leading position belongs to bulk carriers $28 \%$, tugs $13 \%$, each container ships and tankers $11 \%$ and the ammount of crimes on fishing vessels in this area was $3 \%$, the lowest indicator was on gas carriers, it ammounted to 3\%. Genral cargo\&dry ships were attacked in $5 \%$ cases, each oil tankers and chimical tanker were attacked in $7 \%$ crimes, and other vessels 6\%.(GISIS 2019).

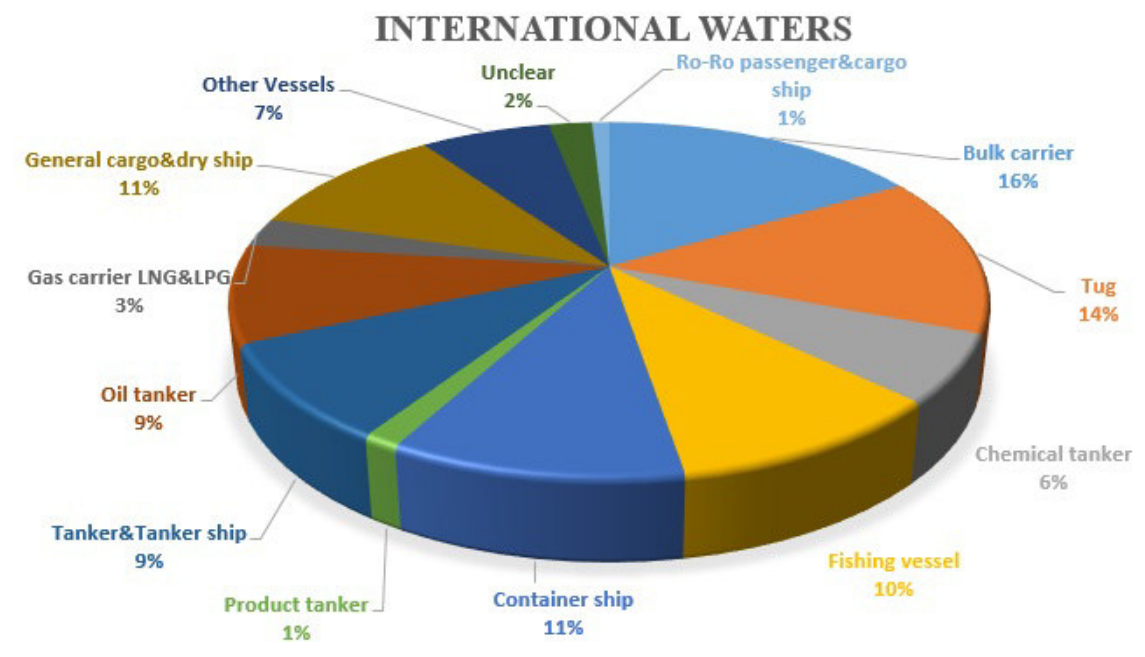

Figure 4. The Incidents in International Waters of the Malacca Strait(GISIS 2019)

Diagram 4 shows that the most common types of ships attacked in international waters of the Strait of Malacca were bulk carrier (16\%), followed by tug $(14 \%)$, container ship $(11 \%)$, general cargo\&dry ship (11\%), fishing vessel
(10\%), tankers (10\%), oil tanker (9\%). Incidents not included in any of these categories represent less than quarter of the incidents (19\%).(GISIS 2019).

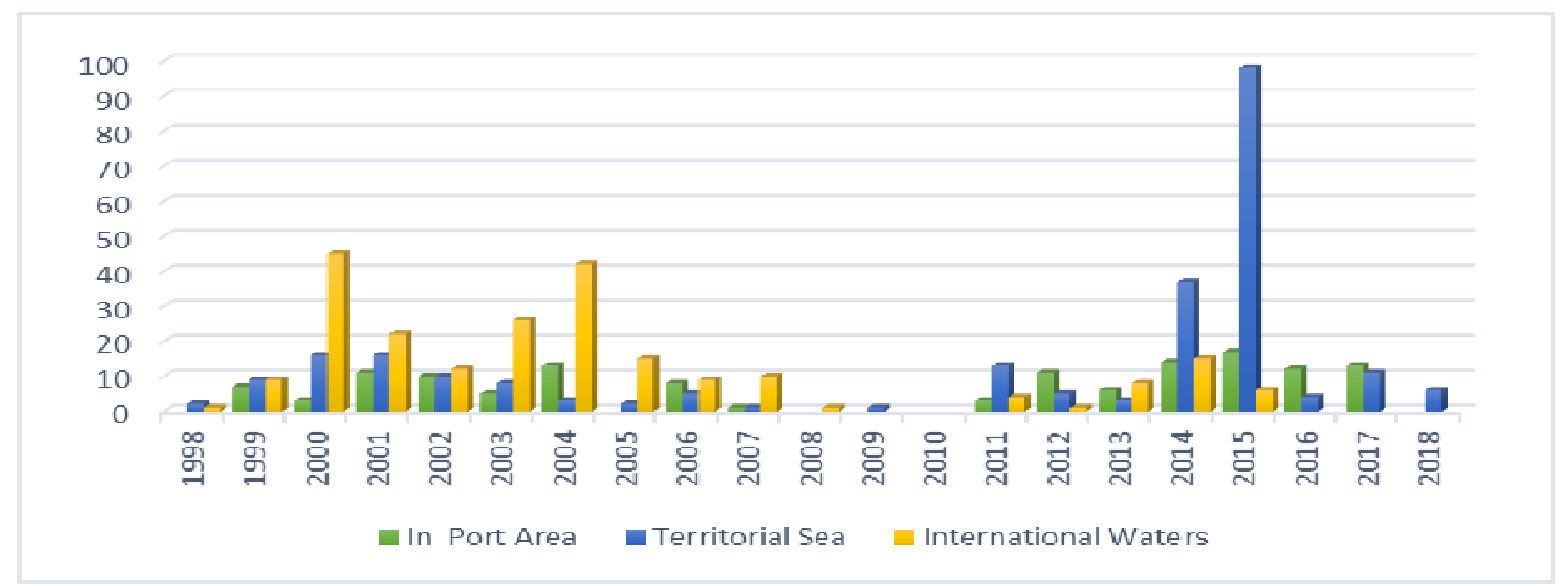

Figure 5. The Annual Incidents in the Strait of Malacca(GISIS 2019)

Figure 5 displays the number of incidents in the Strait of Malacca, occurred in port areas, territorial sea and international waters from 1998 to 2018. It can be observed that major attacks occurred frequently between 1999-2004 and 2011- 2015. Two peaks could be seen when the number of attacks rocketed up to 78 in international waters in 2000 and the highest peak was in territorial sea in 2015, it increased substantially from 42 to 100 . The amount of piracy and armed robbery had slight fluctuation from 2001 to 2005 and from 2013 to 2017. The number of incidents plunged to the minimal number in 2009, during the period from 2008-2010 there were no incidents in port areas.(GISIS 2019). 


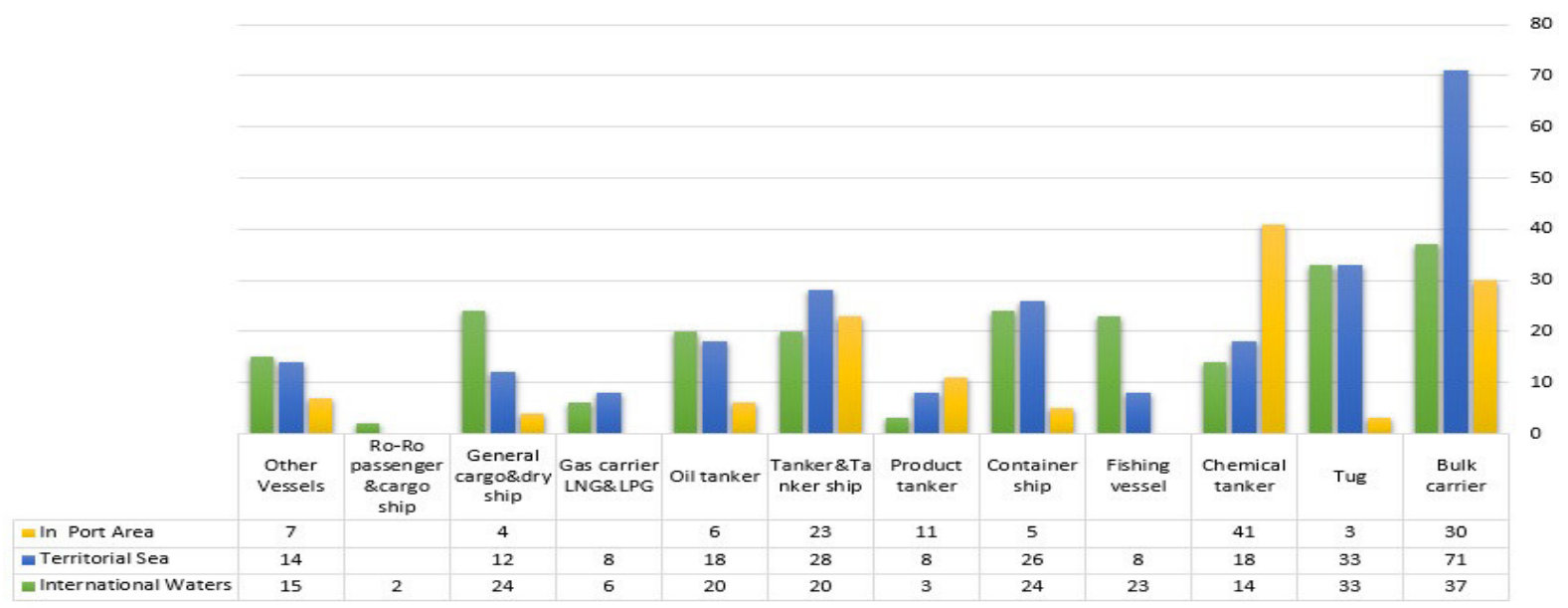

Figure 6. The most Reported Incidents Based on Ship Type in the Malacca Strait(GISIS 2019)

The figure 6 illustrates the most of incidents reported to IMO during the period of 20 years, 1998-2018 occurred in the Strait of Malacca. The data includes the following 8 categories according to the type of ship and quantity: oil tanker/ tanker/product tanker/ chemical tanker; bulk carrier; container ship; tug; general cargo\&dry ship; fishing vessel; gas carrier; Ro-Ro pasanger\&cargo ship. In the Strait of Malacca incidents involving Gas Carrier and fishing vessels were fewer than the other ones. Bulk carriers were attacked more often, it varied from 30 in port area to 71 in territorial sea. Chemical tankers were mostly attacked in port area, 41 cases were reported, while only 14 incidents happened in international waters. The amount of incidents in international waters fluctuated from 2 (Ro-Ro pasanger\&cargo ship) to 37 (bulk carriers). The reports demonstrated that in port area the lowest number of cases happened on the board of 3 tugs and there were 41 cases on the board of chemical tankers. In territorial sea 6 gas carriers were attacked during the reported period but it increased up to 71 on the board of bulk carriers.(GISIS 2019).

\subsection{The South China Sea}

Between 1 January, 1998 and 31 December, 2018, 2089 attacks occurred or were attempted in the SCS as a result of piracy and armed robbery. According to IMO's statistics SCS is one of the most dangerous region in the world and Asia. Amount of incidents in port area of the SCS in comparison with the Malacca Strait was more than three times higher. In territorial waters the number of incidents was more than 2 times higher, and in International waters dominated by half. In comparison with the Malacca Strait the most incidents in the SCS occurred in port and territorial waters, however it occurred in territorial and international waters of the Malacca Strait. Almost $79 \%$ of incidents occered in the Malacca Strait were in port area and territorial waters.

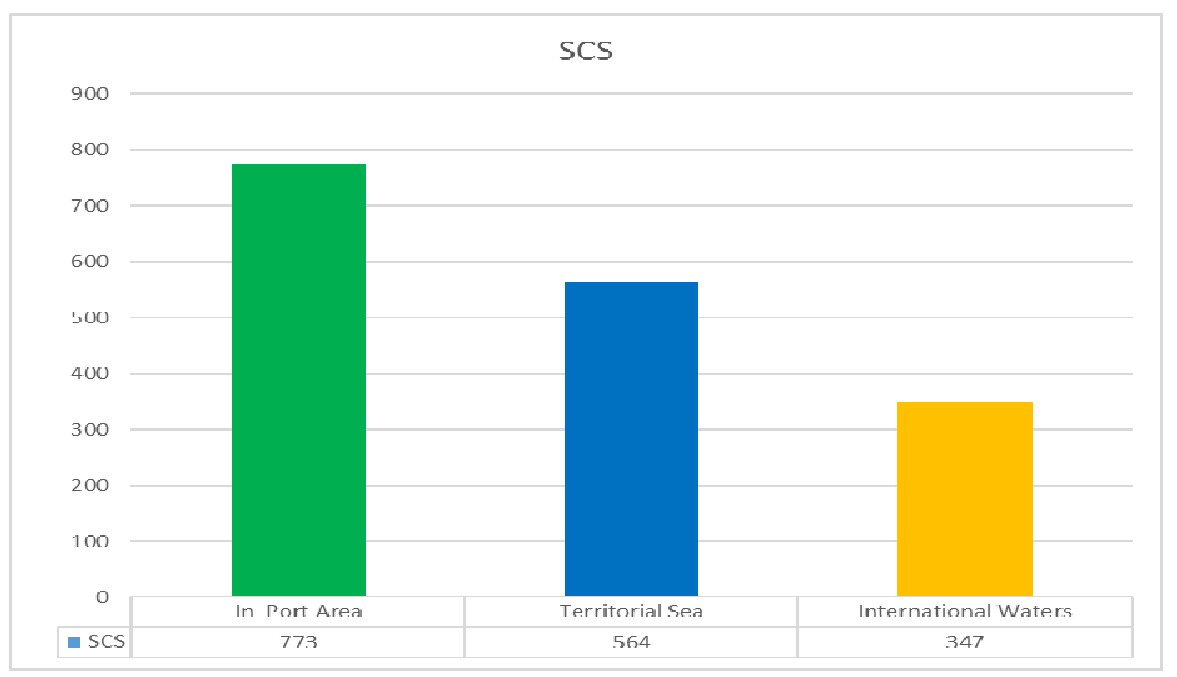

Figure 7. Total number of Piracy and Armed Roberry incidents in the SCS(GISIS 2019) 
The bar chart (Figure7) shows the piracy and armed robbery situation in SCS between 1 January, 1998 and 31 December, 2018. It compares the number of incidents in port area, territorial sea and international waters. The biggest number of crimes happened in port area, it was 773 cases, while territorial sea areas were attacked 564 times. In contrast to the number of piracy and armed robbery incidents in port area, the number of these situations in international waters was twice lower and it was only 347. (GISIS 2019)

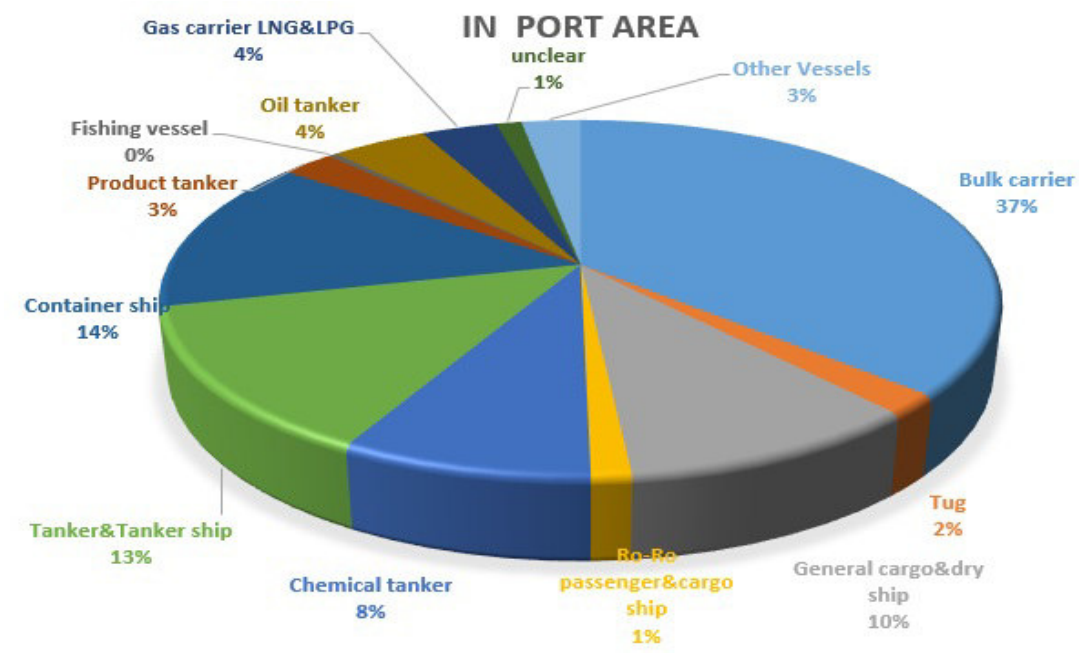

Figure 8. The Reported Incidents in Port Area of the SCS(GISIS 2019)

The figure 8 demonstrates the persentage of various types of ships which were attacked in port area of the SCS. Bulk carriers were attacked in most cases, it was $37 \%$, container ships were robbed in $14 \%$ cases, while general cargo\&dry ships and tankers were $10 \%$ and $13 \%$. Chemical tankers were involved in $8 \%$ situations. Oil tank- ers and gas carriers had to deal with armed robbery in $4 \%$ cases. Unclear ship and other vessels were attacked in $4 \%$ incidents. The less amount of tugs and product tankers were, $2 \%$ and $3 \%$ respectively. Fishing vessels were not attacked during this period of time.(GISIS 2019)

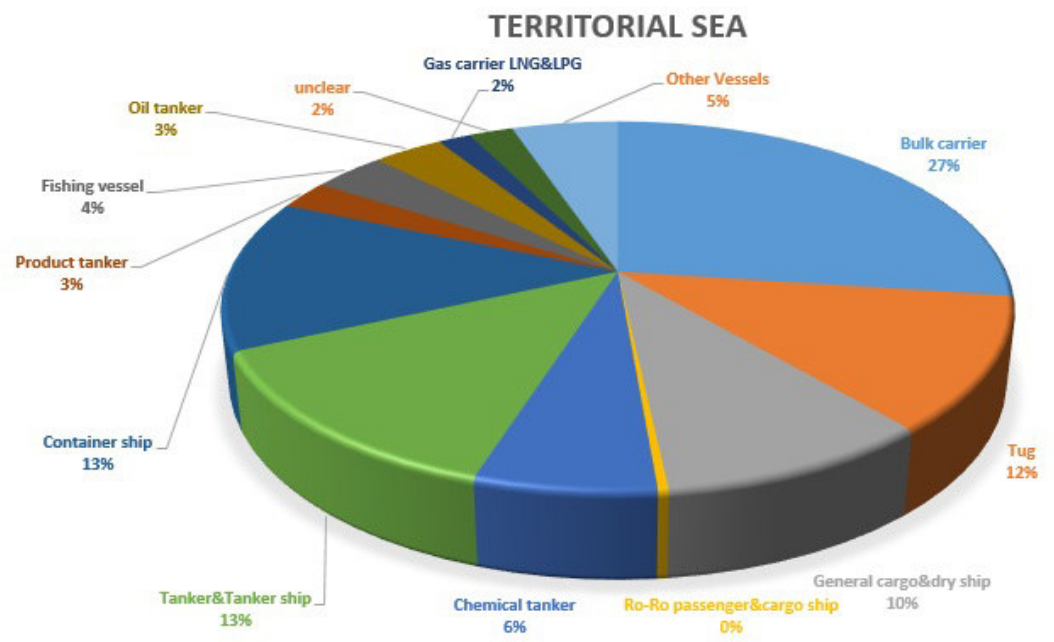

Figure 9. The Reported Incidents in Territorial Sea of the SCS(GISIS 2019)

Figure 9 displays the total number of incidents of piracy against ships in territorial sea in the SCS reported during 1 January, 1998 and 31 December, 2018, 27\% of incidents occurred on board bulk carriers, $13 \%$ on tankers, $6 \%$ on chemical tankers, $10 \%$ on general cargo\&dry ships, $12 \%$ on tug, $7 \%$ unclear and other vessels. In the past 20 -year period $13 \%$ cases happened on container ships and 3\%product tanker, $9 \%$ of the incidents occurred on board of fishing vessels, gas carriers and oil tanker.(GISIS 2019) 


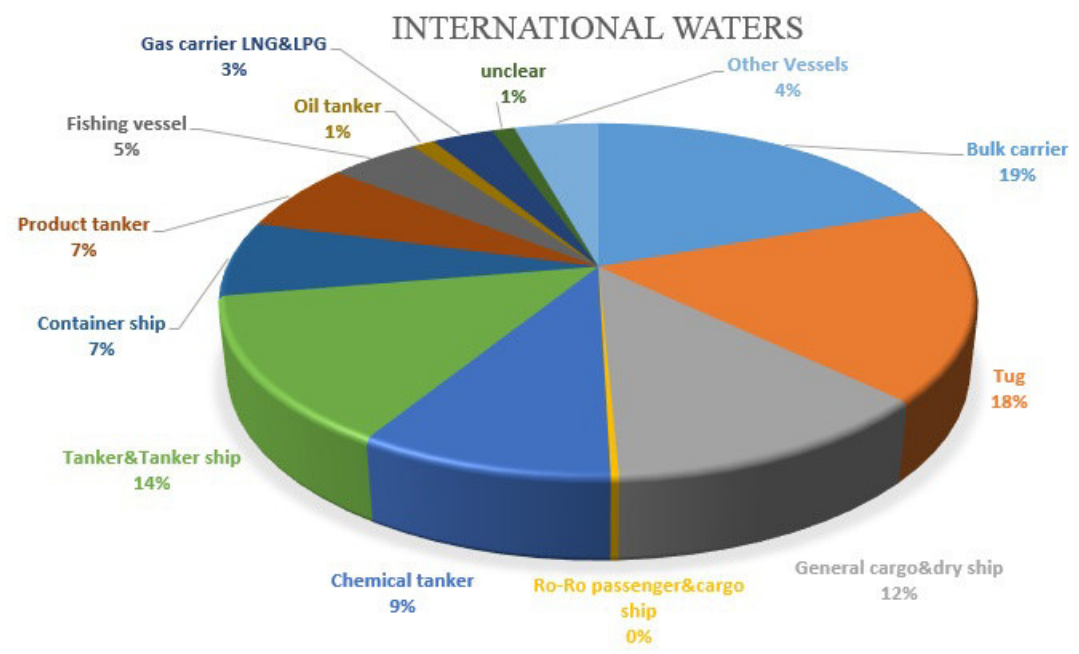

Figure 10. The Reported Incidents in International Waters of the SCS(GISIS 2019)

The figure 10 illustrates the situation in International waters in the SCS. Among the incidents reported during 1 January, 1998 and 31 December, 2018, the most incidents occurred on bulk curriers, $19 \%, 18 \%$ incidents occurred on tugs, and $12 \%$ attacks happened on general cargo\&dry ships, and $14 \%$ tankers. Chemical tankers were attacked in $9 \%$ cases, $5 \%$ fishing vessels, $3 \%$ gas carrier, and $5 \%$ on other vessels and unclear ship. The same number of incidets, $7 \%$, happened on container ship and product tankers. Only $1 \%$ of incidents happened on oil tankers. (GISIS 2019)

\section{The most reported incidents based on ship type in the SCS}

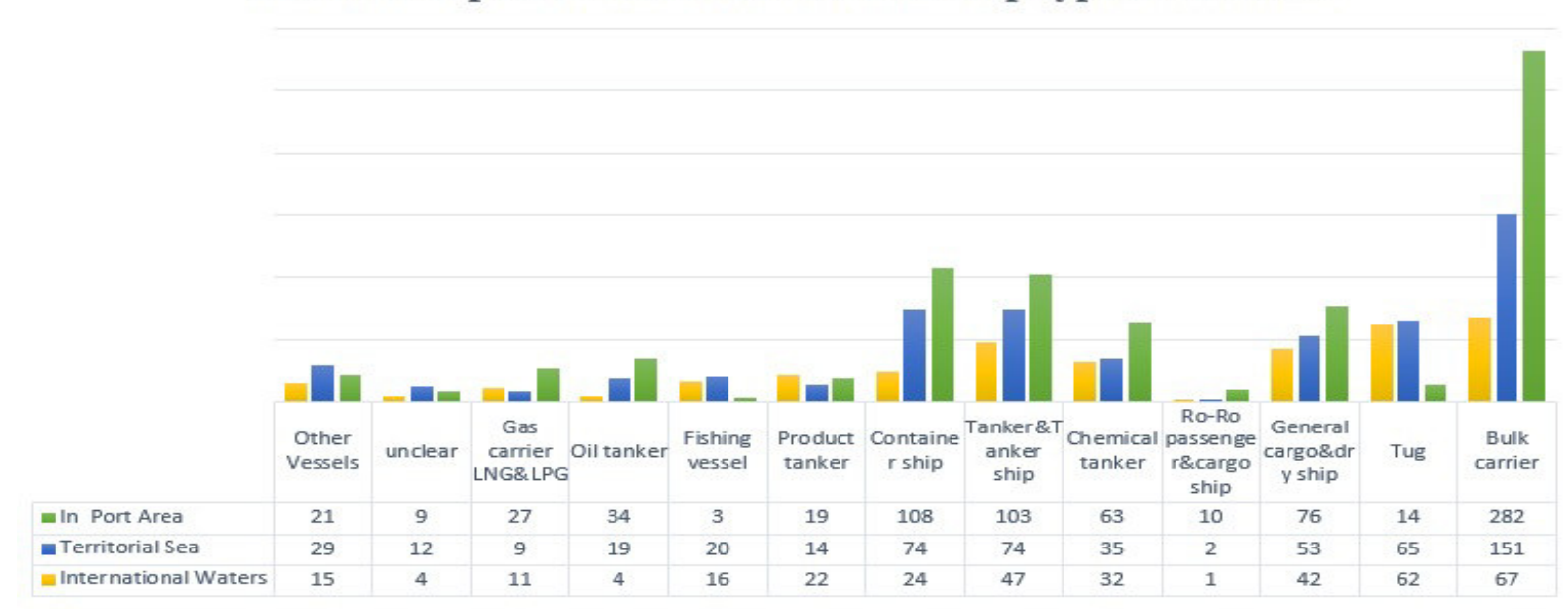

Figure 11. The most reported incidents based on ship type in the SCS(GISIS 2019)

Figure 11 shows that most of incidents reported to IMO during 2008 - 2018 in the SCS, it includes the following 11 categories according to the type of ship and the quantity: in port area the incidents mostly occurred on bulk carriers (282); container ships (108), tankers (103), general cargo\&dry ships (76), chemical tankers (63), oil tankers (34), gas carrier (27), tugs (14), fishing vessels (3), and other vessels (21). The reports about piracy demonstrated that in territorial sea the attacks on vessels were the following: bulk carriers (151), container ships (74), tankers (74), general cargo\&dry ships (53), chemical tankers (35), oil tankers (19), gas carrier (9), tugs (65), and fishing vessels (20), and other vessels (19). The situation in international waters had the same tendencies, the dominating number of attacks were on bulk carriers (67), tugs (62), tankers (47), general cargo\&dry ships (42), chemical tankers (32), container ships (24), product tankers (22), fishing vessels (16), gas carriers (11), oil tankers (4), and other vessels (15).(GISIS 2019). 


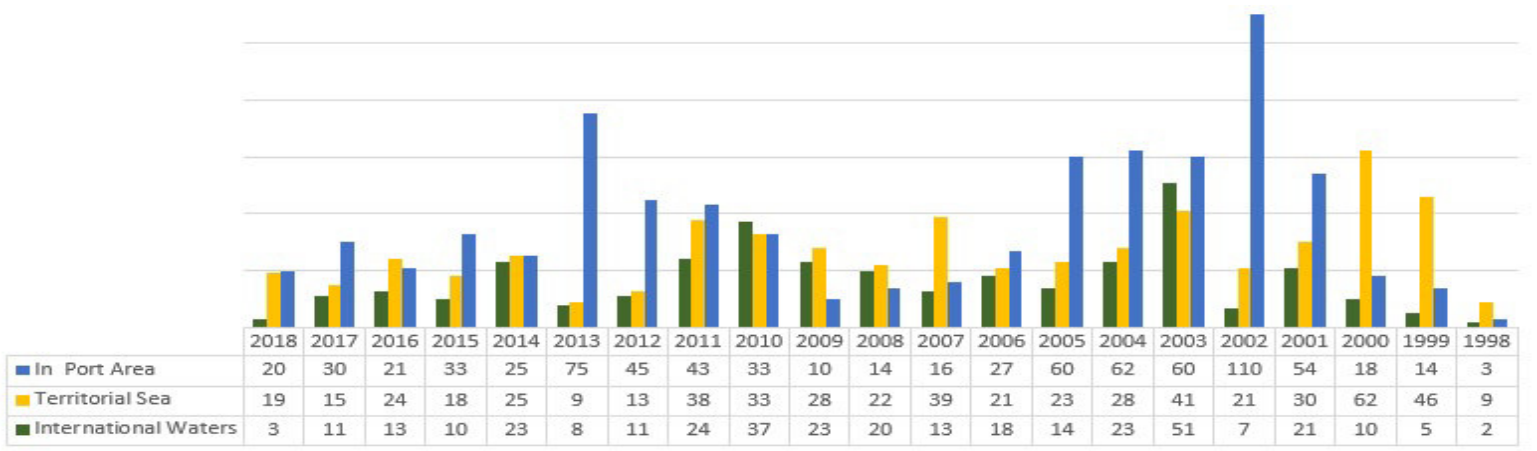

Figure 12. Annual Incidents in the SCS(GISIS 2019)

Figure 12 compares the amount of incidents occurred in SCS between 1998 and 2018 according to the locations of attacks. In port area the number of incidents increased from 3 to 54 from 1998 till 2001, it reached its peak in 2002 and was about 110 , then it rapidly declined to 60 and was at the same level in 2003-2005. The number of attacks in port area was reduced from 2006 and was the lowest in 2009, about 10 . From 2010 till 2013 it rose up to 75. It fluctuated from 20 till 33 in 2014-2018. It can be clearly seen that in territorial sea the number of incidents was the biggest during 1999 till 2000, it was the highest in 1999 , about 62 . Slight decreasing can be seen in 2001-2002. During 2003 till 2018 it fluctuated from 41 to 9 . During the period 1998-2018 the situation in international waters didn't change extremely, it reached its high in 2003, 51 incidents, and it was the lowest in 2018, only about 3. It almost leveled off from 2004 till 2009.(GISIS 2019).

\subsection{Strait of Hormuz}

The Straits of Hormuz is the only gateway that connects the Persian Gulf with the Indian Ocean. This strait borders on two countries, namely Iran in the North and Oman in the South of the Strait. This strait also connects the Persian Gulf with the Gulf of Oman and the Arabian Sea. There are not any tributary waterways along its length, The Strait of Hormuz, its length is about 60 miles long.-The width of the Hormuz Strait between southern Great Quoin and eastern part of Jezirat Larak is 22.5 miles, it is only 1 mile narrower between Great Quoin and the southwestern end of Jezirat Larak. The distance between Perforated Rock and the south-western end of Jezirat Larak is 26 miles.-The narrowest place at the Strait, connecting Great Quoin and Jezirat Larak is $203 / 4$ miles,(Kennedy 1958) while the shipping lane's width in any direction is only 2 miles and it's separated by the buffer zone, which width is also 2 miles. (EIA 2017b).

\subsection{Importance of Hormuz}

The Strait of Hormuz is the main maritime route through which the Persian Gulf exporters (Bahrain, Iran, Iraq, Kuwait, Qatar, Saudi Arabia, and the United Arab Emirates) ship their oil to external markets. The Strait of Hormuz is considered to be the most important oil chokepoint in the world because in 2011 about 17 million barrels $(\mathrm{bbl} / \mathrm{d})$ were transported every day. The amount of the world traded oil transported in the Strait of Hormuz was reduced from 35\% in 2011 to $20 \%$ in 2009-2010.)EIA 2012b) The peak high of total flows through the Strait of Hormuz was in 2016 and it rose up to 18.5 million b/d.(EIA 2017b) Increasing amount of foreign oil is necessary for Asia, for example, only China's need reached 5 million barrels per day in 2015 and $9,261.414$ barrels per day (b/d) in 2018.(CEIC n.d.) The main amount of oil has to come from the Persian Gulf as it is the depository of the world's largest oil reserves.(Kemp 1998) China, India, South Korea, and Japan, being the most important Asian economies, will demand more energy, oil will be one of the most important need. It is expected that the main oil demand will concern the Persian Gulf. The US Energy Information Agency supposes that in 2020 North America's oil needs of will be $20 \%$ of the total needs of its imported oil. The needs of Western Europe are estimated at 31\% and Asia's - at 86\%.(Kemp 1998) According to U.S. research firm ClipperData, the top destinations for crude oil from the strait of Hormuz are China at $18 \%$ of shipments in 2018 , followed by India at $16 \%$ and Japan at $14 \%$. (NAGASAWA,TSUYOSHI and KIBE 2019) Table1. 
Table 1

Crude oil, condensate, and petroleum products transported through the Strait of Hormuz, Million barrels per day(EIA 2019)

\begin{tabular}{|c|c|c|c|c|c|}
\hline & 2014 & 2015 & 2016 & 2017 & 2018 \\
\hline Total oil flow through Strait of Hormuz & 17.2 & 18.4 & 20.6 & 20.3 & 20.7 \\
\hline Crude and condensate & 14.4 & 15.2 & 17.3 & 17.2 & 17.3 \\
\hline Petroleum products & 2.8 & 3.2 & 3.3 & 3.1 & 3.3 \\
\hline World maritime oil trade & 56.4 & 58.9 & 61.2 & 62.5 & $\mathrm{~N} / \mathrm{A}$ \\
\hline $\begin{array}{l}\text { World total petroleum and other liquids consump- } \\
\text { tion }\end{array}$ & 93.9 & 95.9 & 96.9 & 98.5 & 99.9 \\
\hline LNG flows through Strait of Hormuz (TCF per year) & 4.0 & 4.2 & 4.2 & 4.1 & 4.1 \\
\hline
\end{tabular}

The Strait of Hormuz, the Straits of Malacca and Singapore are the most important lifeline on the planet)Rusli 2012). We can describe these straits as Straits of sellers and suppliers. With the growing economic of the East Asian Countries including China, South Korea and Japan and the need of western countries in oil, the Straits of Hormuz, Malacca and Singapore will enhance their significance as the heart of economic and strategic activities. Energy Information Administration (EIA) demonstrates that According to the data from Lloyd's List Intelligence tanker tracking service Asian countries consume about $80 \%$ of the crude oil, transported through these straits.)EIA 2017b) Grain, cement and raw iron are delivered through the Hormuz, that is about $22 \%$ of the world commodities. $88 \%$ of oil production exported from Saudi Arabia is delivered through the Strait of Hormuz. $98 \%$ of Iraqi and $99 \%$ of UAE oil are exported through the Straight.)AMCO 2017) 3.7 trillion cubic feet of liquefied natural gas were exported from Qatar through Hormuz according to BP's Statistical Review of World Energy 2017.(EIA 2017b)

\subsection{The Persian Gulf and the Strait of Hor-} muz

The Persian Gulf is a leading oil-producing region, accounting for $30 \%$ of global supply. Meanwhile, East Asia is a major oil-consuming region and accounts for $85 \%$ of the Persian Gulf's exports, according to the EIA. The most common route for oil deliveries between these two regions is through the Strait of Hormuz, into the Indian Ocean, and through the Strait of Malacca.

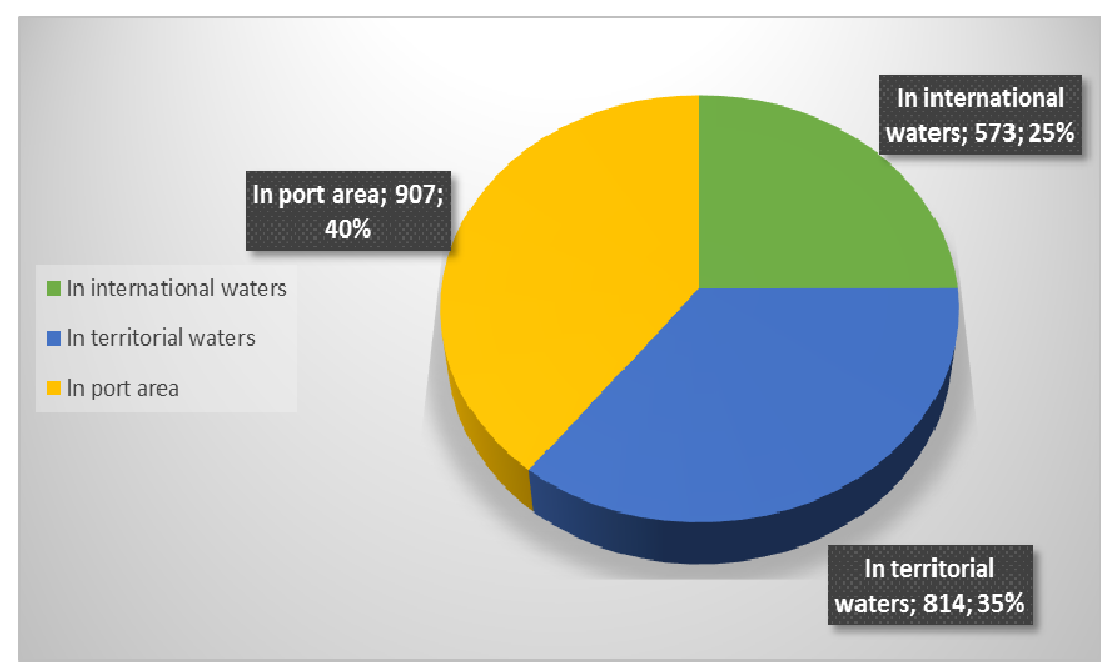

Figure 13. The Regional Analysis of Incidents in the Persian Gulf and the Strait of Hormuz

The figure 13 illustrates the situation in the Persian Gulf and the Strait of Hormuz according to the number of incidents happened in territorial waters (10), number of attacks in international waters and port area were 4 and 3 incidents respectively. According to IMO's report total piracy and armed robbery in the Persian Gulf were 17 attacks. There were only 1 oil tanker were re- ported during 20 years. Diagram 13 demonstrates the level of security in the Persian Gulf as it is quite different in comparison with Malacca Strait and the SCS. There are egregious differences between the Persian Gulf and the two areas namely the SCS and the Malacca Strait. The Strait of Hormuz is a vital shipping route that has been the focal point of regional tensions for decades. 
Roughly $30 \%$ of the world's sea-borne crude oil passes through the strategic point, making it a flashpoint for political and economic friction. The strait is only 21 miles wide at its narrowest point, but is deep enough to handle the biggest tankers as $80 \%$ of the crude it handles destined for markets in Asia.(GISIS 2019)

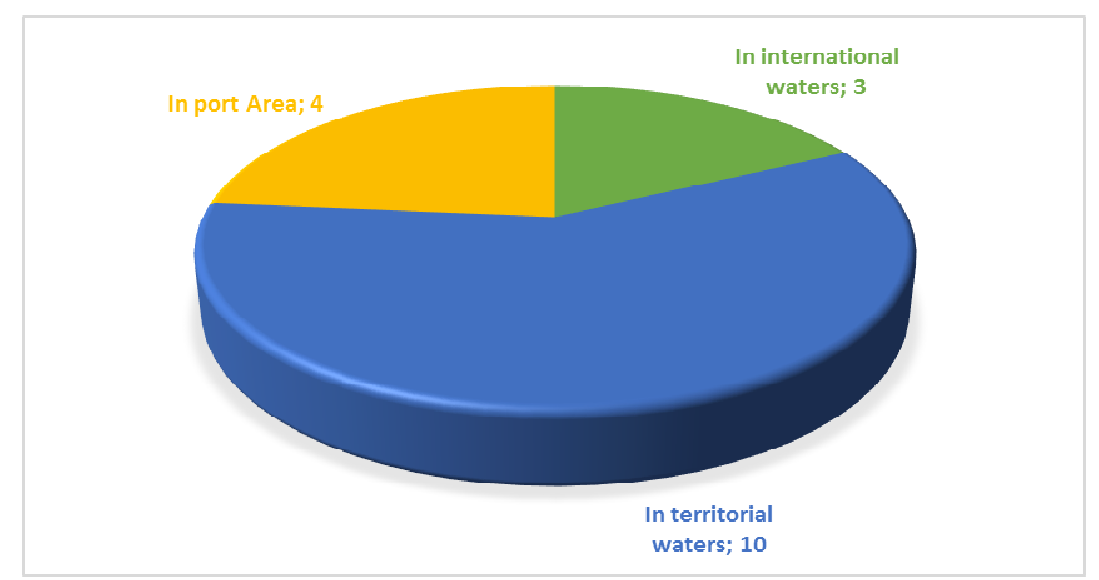

Figure 14. Total Reported Incidents in the SCS and the Strait of Malacca

The figure 14 shows that most of attacks in the Strait of Malacca and the SCS occurred in port area $(40 \%)$, territorial waters $(35 \%)$ and in international waters $(25 \%)$ between $1998-2018$. The quantities of piracy in territorial waters and in port area of the Strait of Malacca and the SCS Sea was much higher than in international waters in the same regions. Figure 14 illustrates that Islamic Republic of Iran has well established security in the Persian Gulf, Strait of Hormuz and also the beyond its territory. Therefore, the marine security in the Persian Gulf and the geopolitical strait in this region namely the Strait of Hormuz in comparison with mentioned above two areas is egregiously secure.-This figure reflects mainly the percentage of piracy, leading to 2294 incidents. The number of incidents is extremely high and therefore it has a deep impact on the maritime security.(GISIS 2019).

\section{Conclusion}

This article presents the comparison of strategic areas, the main MSR, namely from the SCS to the Strait of Malacca and from the Strait of Hormuz to the Persian Gulf. This analysis has shown that the Malacca Strait and the South China Sea areas became the location of the most crime incidents (piracy and armed robberies) for a long time. As most incidents took place in the SCS and the Malacca Strait this can be concluded that these two geopolitics and geographic areas have the highest level of insecurity. This comparison is based on the incidents occurred from the early of 1998 to the end of 2018, it was carried out through the zone by zone comparison (IMO's reports), which emphasizes the significance of a regional insecurity. The significant fluctuation can be seen during the 20 years' period. Numerous incidents occurred in the South China Sea and the Strait of Malacca made them the most dangerous hotspot during two decades. From the information referred to this study, it emerges that the regions most affected during two decades were international water and territorial sea, in particular, the Strait of Malacca and the South China Sea.

As it has already been illustrated in this article, it is obvious the SCS and the Strait of Malacca are endangered or threatened by the crimes of piracy or armed robbery. The analyzed statistics demonstrates that attacks in port areas were more frequent in the South China Sea in comparison with the Strait of Malacca. The total number of incidents of piracy and armed robbery against ships, which occurred or were attempted in the area 1 from 1998 to the end of 2018, was 17 incidents and in the area 2, it was 2294 incidents. That is why the Iranian strategy in the Persian Gulf and the Strait of Hormuz could be used as a successful pattern to ensure maritime security in this strategic waterway. It can become an effective means to help another country to improve their security situation in different maritime areas with Iranian support. From the point of view of direct security, the number of reported events to the GISIS (2294 incidents) shows clearly that two regions of the South China Sea and the Strait of Malacca are extremely insecure for the past two decades. On the contrary, the reported incidents (17 incidents) in the Persian Gulf region and the Strait of Hormuz prove that these areas are very safe and there is a safe transit through this area free of fear and worry. Thus, it owed the extraordinary qualities of statesmanship, intelligence, and foresight that Iran's leadership has shown since the 1978 Iran's Islamic revolution. 


\section{Reference List}

1. AMCO. 2017. "Navigation Traffic.. Importance and Impact on World Trade." http://amcogroup.co/ navigation-traffic/ (April 20, 2018).

2. Attard, Felicity. 2014. "IMO's Contribution to International Law Regulating Maritime Security." Journal of Maritime Law \& Commerce, 45(4): 479-565.

3. Balkin, Rosalie. 2006. "The International Maritime Organization and Maritime Security." Tulane Maritime Law Journal 30: 1-34. http://heinonlinebackup.com/hol-cgi-bin/get_pdf.cgi?handle=hein.journals/ tulmar30\&amp;section $=4$.

4. Barrios, Erik. 2005. "Casting a Wider Net: Addressing the Maritime Piracy Problem in Southeast." Boston College International and Comparative Law Review 28(1): 149-63.

5. Bornick, Brooke A. 2005. "Bounty Hunters and Pirates Filling in the Gaps of the 1982 U.N. Convention on the Law of the Sea." Florida Journal of International Law 17: 259-70.

6. Caskey, John L. 1969. "Crises in the Minoan-Mycenaean World." Proceedings of the American Philosophical Society 113(6): 433-49.

7. CEIC. "China Crude Oil: Imports [1980 - 2019] [Data \&amp; Charts]." https://www.ceicdata.com/ en/indicator/china/crude-oil-imports (August 8, 2019).

8. Djalal, Hasjim. 1999. "Funding and Managing International Partnership for the Malacca and Singapore Straits Consonant with Article 43 of the UNCLOS, 1982." Singapore Journal of International \& Comparative Law 3(2): 457-69.

9. EIA. 2012a. "The Strait of Hormuz Is the World's Most Important Oil Transit Chokepoint." EIA. https://www.eia.gov/todayinenergy/detail.php?id=4430 (August 18, 2019).

10. EIA. 2012b. "The Strait of Hormuz Is the World's Most Important Oil Transit Chokepoint." U.S. Energy Information Administration: 1. https://www.eia.gov/todayinenergy/detail.php?id=4430 (April 20, 2018).

11. EIA. 2017a. "Maritime Chokepoints Are Critical to Global Energy Security." EIA. https://www.eia.gov/todayinenergy/detail.php?id=32292 (August 18, 2019).

12. EIA. 2017b. "Profile World Oil Transit Chokepoints." EIA. https://www.eurasiareview.com/ 26072017-profile-world-oil-transit-chokepoints-analysis/ (April 20, 2018).

13. EIA. 2019. "The Strait of Hormuz Is the World's Most Important Oil Transit Chokepoint." EIA. https://www.eia.gov/todayinenergy/detail.php?id=39932 (August 21, 2019).

14. Emran, Amelia. 2007. "The Regulation of Vessel-Source Pollution in the Straits of Malacca and Singapore." Australian National Centre for Ocean Resources \& Security. http://ro.uow.edu.au/theses/60.

15. Forbes, Vivian Louis. 2004. "The Malacca Strait in the Context of the ISPS Code." In The Straits of Malacca: Building A Comprehensive Security Environment, Kuala Lumpur: MIMA.

16. George, Mary. 2008. Legal Regime of the Straits of Malacca and Key Benefits. LexisNexis Malaysia Sdn Bhd,

17. Gilmartin, Heather. 2008. "U.S.-China Cooperation in the Malacca Straits." Institut für Friedensforschung und Sicherheitspolitik an der Universität Hamburg 6.

18. GISIS. 2019. GISIS. https://gisis.imo.org/Public/PAR/Search.aspx (August 21, 2017).

19. Graham, Euan. 2006. Japan's Sea Lanse Security A Matter of Life and Death. London: Routledge Japanese Studies Series.

20. Hazmi, Mohd. 2011. "The Application of Compulsory Pilotage in Straits Used for International Navigation: A Study of the Straits of Malacca and Singapore." Asian Politics \& Policy 3(4): 501-26. http://doi.wiley.com/10.1111/j.1943-0787.2011.01291.x.

21. Ho, Joshua. 2009. "Combating Piracy and Armed Robbery in Asia: The ReCAAP Information Sharing Centre (ISC)." Marine Policy 33(2): 432-34. http://www.sciencedirect.com/science/article/pii/ S0308597X08001449.

22. Ho, Joshua H. 2009. "Enhancing Safety, Security, and Environmental Protection of the Straits of Malacca and Singapore: The Cooperative Mechanism." Ocean Development and International Law 40(2): 233-47.

23. Huang, Victor. 2008. "Building Maritime Security in Southeast Asia." Naval War Review 61(1): 87-105.

24. IMO. "Piracy and Armed Robbery against Ships." IMO. http://www.imo.org/en/OurWork/Security/ PiracyArmedRobbery/Pages/Defaultaspx (July 21, 2018).

25. J. Ashley Roach. 2011. "General Problematic Issues on Exercise of Jurisdiction over Modern Instances of Piracy." In Selected Contemporary Issues in the Law of the Sea, Martinus Nijhoff, 1-360.

26. J.N. Mak. 2006. "Unilateralism and Regionalism: Working Together and Alone in the Malacca Straits." In Piracy, Maritime Terrorism and Securing the Malacca Straits, ed. Graham Gerard Ong-Webb. , 134-62.

27. Jesus, H.E. Jose Luis. 2003. "Protection of Foreign Ships against Piracy and Terrorism at Sea: Legal Aspects." International Journal of Marine and Coastal Law 19(1): 363-400.

28. Jones, H Stuart. 1926. "A Roman Law Concerning Piracy." The Journal of Roman Studies 16: 155-73.

29. Katzman, Kenneth, Ronald O Rourke, R Chuck Mason, and Michael Ratner. 2012. "Iran's Threat to the Strait of Hormuz." Congressional Research Service Report. https://fas.org/sgp/crs/mideast/R42335.pdf. 
30. Kemp, G. 1998. “The Persian Gulf Remains the Strategic Prize.” Survival 40(4): 132-49.

31. Kennedy, R. H. 1958. "United Nations Conference on the Law of the Sea: A Brief Geographical and Hydro Graphical Study of Straits Which Constitute Routes for International Traffic.” I(April 1958).

32. Kevin X. Li; Jin Cheng. 2006. "Maritime Law and Policy for Energy Security in Asia a Chinese Perspective." 1: 567-88.

33. Keyuan, Zou. 2000. "Redefining the Legal Status of the Taiwan Strait." International Journal of Marine and Coastal Law 15(2): 245-74.

34. Koto, J, M Rashidi, and A Maimun. 2013. "Tracking of Ships Navigation in the Strait of Malacca Using Automatic Identification System." Developments in Maritime Transportation and Exploitation of Sea Resources (March): 721-25.

35. "Marine Department Malaysia." Numbers of Ships Reporting Under STRAITREP. http://www.marine.gov.my/jlmeng/Contentdetail.asp?article_id=245\&category_id=4\&subcategory_id=42\& subcategory2_id=0\#.WvqUy4q-nIU (May 15, 2018).

36. Mejia, Max Jr. 2003. "Maritime Gerrymandering: Dilemmas in Defining Piracy, Terrorism and Other Acts of Maritime Violence." Journal of International Commercial Law 2(2): 153-75.

37. MO, JOHN. 2002. "Options to Combat Maritime Piracy in Southeast Asia." Ocean Development \& International Law 33(3-4): 343-58.

38. NAGASAWA,TSUYOSHI and KIBE, HIDEMITSU. 2019. "Asian Oil Buyers Tested by US Plan for Gulf Coalition - Nikkei Asian Review.” Nikkei. https://asia.nikkei.com/Politics/International-relations/Asian-oilbuyers-tested-by-US-plan-for-Gulf-coalition (August 8, 2019).

39. Nazemroaya, Mahdi Darius. 2012. "The Geo-Politics of the Strait of Hormuz: Could the U.S. Navy Be Defeated by Iran in the Persian Gulf?" Global Research. https://www.globalresearch.ca/the-geo-politics-ofthe-strait-of-hormuz-could-the-u-s-navy-be-defeated-by-iran-in-the-persian-gulf/28516 (April 20, 2018).

40. Oei, Parry. 2003. "Review of Recent Significant Technologies and Initiatives Implemented to Enhance Navigational Safety and Protect the Marine Environment in the Straits of Singapore and Malacca." In The Strategic Importance of Seaborne Trade and Shipping, ed. Andrew Forbes. Canberra, Australia: Royal Australian Navy Sea Power Centre, 141-52.

41. Pearson, Andrew. 2006. "Piracy in Late Roman Britain: A Perspective from the Viking Age." Britannia 37(2006): 337-353.

42. Rahman, N.S.F. Abdul, A.H. Saharuddin, and R. Rasdi. 2014. "Effect of the Northern Sea Route Opening to the Shipping Activities at Malacca Straits." International Journal of e-Navigation and Maritime Economy 1: 85-98. http://linkinghub.elsevier.com/retrieve/pii/S2405535214000096.

43. Rusli, Mohd Hazmi Bin Mohd. 2012. "Protecting Vital Sea Lines of Communication: A Study of the Proposed Designation of the Straits of Malacca and Singapore as a Particularly Sensitive Sea Area." Ocean and Coastal Management 57: 79-94. http://dx.doi.org/10.1016/j.ocecoaman.2011.12.003.

44. Sien, Chia Lin. 1998. "The Importance of the Straits of Malacca and Singapore." Singapore Journal of International \& Comparative Law 2(2): 301-22.

45. Sivaguru, H.M Ibrahim and Hairil Anuar Husin and Deneswari. 2008. "The Straits of Malacca: Setting the Scene." In Profile of the Straits of Malacca: Malaysia's Perspective, ed. H.M Ibrahim and Hairil Anuar Husin. Kuala Lumpur: Maritime Institute of Malaysia, 31-38.

46. Storey, Ian. 2008. "Securing Southeast Asia's Sea Lanes: A Work in Progress.” Asia Policy 6(1): 95-128.

47. Teo, Yun Yun. 2007. "Target Malacca Straits: Maritime Terrorism in Southeast Asia." Studies in Conflict and Terrorism 30(6): 541-61.

48. Vespe, Michele, Harm Greidanus, and Marlene Alvarez Alvarez. 2015. "The Declining Impact of Piracy on Maritime Transport in the Indian Ocean: Statistical Analysis of 5-Year Vessel Tracking Data." Marine Policy 59(December 2008): 9-15. http://dx.doi.org/10.1016/j.marpol.2015.04.018.

49. Woolley, Carrie R. 2010. "Piracy and Sovereign Rights : Addressing Piracy in the Straits of Malacca Without Degrading the Sovereign Rights of Indonesia and Malaysia." Santa Clara Journal of International Law: 447-72.

50. Zaman, Muhammad Badrus, Eiichi Kobayashi, Nobukazu Wakabayashi, and Adi Maimun. 2015. "Risk of Navigation for Marine Traffic in the Malacca Strait Using AIS." Procedia Earth and Planetary Science 14: 33-40. http://linkinghub.elsevier.com/retrieve/pii/S1878522015002337.

Came to the Editorial Board 11 July 2019

\section{МОХАММАД АЛИ ЗОХУРИАН СТАТИСТИЧЕСКОЕ СРАВНЕНИЕ ПИРАТСТВА И ВООРУЖЕННЫХ ОГРАБЛЕНИЙ С АКЦЕНТОМ НА ЮЖНО-КИТАЙСКОМ МОРЕ - ПРОЛИВЕ МАЛАККА И ПЕРСИДСКОМ ЗАЛИВЕ - ОРМУЗСКОМ ПРОЛИВЕ}

Международные торговые потоки всегда были предметом геополитических рисков и конфликтов. На разных этапах поставок торговля всегда сталкивается с присущими ей 
вызовами, вызванными геополитическими реалиями на определенных маршрутах. В этом исследовании были учтены данные о пиратстве и вооруженных ограблениях судов в соответствии с Глобальной интегрированной информационной системой судоходства. Статистика включает информацию об инцидентах за период между 1998 и 2018 годами на различных типах кораблей в двух стратегических районах: Южно-Китайском море (ЮКМ) и проливе Малакка (район 1); Ормузском проливе и Персидском заливе (район 2). Согласно сообщениям GISIS, большинство инцидентов произошло в ЮжноКитайском море и проливе Малакка - 1684 и 610 случаев соответственно. Из-за большого значения как Ормузского пролива, так и пролива Малакка, которые являются важнейшими водными путями мира, необходимо иметь четкую картину ситуации безопасности в этих проливах.

Это исследование позволило: 1) выявить различие между безопасностью в двух упомянутых районах; 2) представить источник информации для исследователей.

Ключевые слова: Персидский залив, Ормузский пролив, пролив Малакка, ЮжноКитайское море, пиратство и вооруженные ограбления.

\section{МОХАММАД АЛІ ЗОХУРІАН СТАТИСТИЧНЕ ПОРІВНЯННЯ ПІРАТСТВА

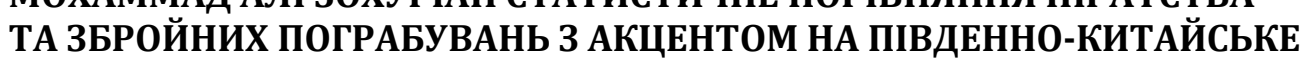 МОРЕ - ПРОТОКУ МАЛАККА ТА ПЕРСЬКУ ЗАТОКУ - ОРМУЗСЬКУ ПРОТОКУ}

Міжнародні торговельні потоки завжди були предметом геополітичних ризиків і конфліктів. На різних етапах поставок торгівля завжди стикається з притаманними їй викликами, спричиненими геополітичними реаліями на певних маршрутах. У цьому дослідженні були враховані дані про піратство та збройні пограбування суден відповідно до Глобальної інтегрованої інформаційної системи судноплавства. Статистика включає інформацію про інциденти за період між 1998 та 2018 роками на різних типах кораблів у двох стратегічних районах: Південно-Китайське море (ПКМ) і протока Малакка (район 1); 0pмузська протока та Перська затока (район 2). Згідно з повідомленнями GISIS, більшість інцидентів сталося в Південно-Китайському морі та протоці Малакка -1684 та 610 випадків відповідно. Через велике значення як Ормузської протоки, так і протоки Малакка, які $\epsilon$ найважливішими водними шляхами світу, необхідно мати чітку картину ситуації щодо безпеки в цих протоках.

Це дослідження дозволило: 1) виявити відмінність між безпекою у двох згаданих районах; 2) представити джерело інформації для дослідників.

Ключові слова: Перська затока, Ормузська протока, протока Малакка, ПівденноКитайське море, піратство та збройні пограбування. 